\title{
PEMANFATAN TUMBUHAN SEBAGAI BAHAN RUM-RUMEN (MINUMAN KESEHATAN ETNIS KARO) OLEH PEDAGANG TUMBUHAN OBAT DI PASAR PANCUR BATU SUMATERA UTARA
}

\author{
Marina Silalahi \\ Prodi Pendidikan Biologi FKIP, Universitas Kristen Indonesia, Jakarta. \\ E-mail : marina biouki@yahoo.com; marina.silalahi@uki.ac.id
}

\begin{abstract}
Written documentation of local knowledge about health drinks, especially the Karo ethnic group, is still limited, although degradation is accelerating with the introduction of information technology. This study aims to determine the diversity of rum-rumen plants, their properties and bioactivity. The method used in the survey and in-depth interviews of 11 traders of medicinal plants is used as a material for making rumrumen and their benefits. Respondents in this study were all traders of medicinal plants in the Pancurbatu market who traded rum-rumen material. The data obtained were analyzed qualitatively and descriptively. The results showed that the rum-rumen is a health drink derived from extracts of 6 plant species originating from 3 families. Leaves and stems are the most widely used organs. The benefits of rum rumen are blood circulation, overcoming headaches, overcoming digestive tract disorders, treating cholesterol and also antibypertension. The conclusion that all types of plants used as ruminal ingredients are rich in essential oils. The three plants are Ocimum basilicum, Plectranthus amboinicus and Cymbopogon citratus as the main ingredient of rumen have bioactivity as antimicrobial and anti-cancer especially microbes that infect the digestive and respiratory tract. Rum-rumem drink is very potential to be developed into a bealth drink to treat digestive and respiratory disorders.
\end{abstract}

Keywordsc: Rum-rumen; antimicrobial; essential oil; health drinks.

\begin{abstract}
ABSTRAK
Dokumentasi secara tertulis pengetahuan lokal tentang minuman kesehatan khususnya etnis Karo masih terbatas, padahal degradasinya semakin cepat seiring dengan masuknya teknologi informasi. Penelitian ini bertujuan untuk mengetahui keankeragaman tumbuhan penyusun rum-rumen, khasiat dan bioaktivitasnya. Metode yang digunakan dalam dengan survei dan wawancara mendalam pada pada 11 pedagang tumbuhan obat yang digunakan sebagai bahan pembuatan rum-rumen dan manfaatnya. Responden yang dalam penelitian ini merupakan semua pedagang tumbuhan obat di pasar Pancurbatu yang memperjualbelikan bahan rum-rumen. Data yang diperoleh dianalisa secara kualitatif dan dekriptif. Hasil penelitian menunjukkan bahwa rum-rumen merupakan minuman kesehatan


yang berasal dari ekstrak 6 species tumbuhan yang bersala dari 3 famili. Daun dan batang merupakan organ yang paling banyak digunakan. Manfaat rum-rumen adalah melancarkan peredaran darah, mengatasi sakit kepala, mengatasi gangguan saluran pencernaan, mengobati kolesterol dan juga anti hipertensi. Kesimpulan bahwa semua jenis tumbuhan yang digunakan sebagai bahan rum-rumen kaya akan essensial oil. Ketiga tanaman Ocimum basilicum, Plectranthus amboinicus dan Cymbopogon citratus sebagai bahan utama rum-rumen memiliki bioaktivitas sebagai antimikroba dan anti kanker terutama mikroba yang menginfeksi saluran pencernaan dan pernapasan. Minuman rum-rumen sangat potensial dikembangkan menjadi minuman kesehatan untuk mengatasi gangguan saluran pencernaan dan pernapasan.

Kata Kunci: Rum-rumen; antimikroba; esential oil; minuman kesehatan.

\section{PENDAHULUAN}

Minuman kesehatan telah lama digunakan masyarakat Indonesia dalam menjaga kesehatannya. Etnis di Indonesia memiliki minuman tradisional yang yang relatif berbeda antara satu etnis dengan etnis lainnya seperti loloh oleh etnis Bali Aga (Sujarwo et al 2014), befufu oleh etnis Lako Akediri (Wahkidah 2015), jamu, wedang oleh etnis Jawa, bandrek dan bajigur oleh etnis Sunda. Minuman kesehatan pada umumnya dibuat dari berbagai jenis tumbuhan yang dikenal jug sebagai tumbuhan nutracetikal. Sujarwo et al (2014) menyatakan bahwa ditemukan sebanyak 52 species tumbuhan obat yang digunakan dalam pembuatan loloh dan diyakini berkhasiat untuk mengatasi berbagai penyakit seperti sakit perut, demam, diare, hipertensi, dan gangguan lambung.
Berbagai fakta menunjukkan bahwa dokumentasi pengetahuan lokal khususnya minuman tradisioanal masih terbatas, padahal degradasinya terus berlansung seiring dengan masuknya teknologi informasi. Disisi lain pemanfaatan obat tradisional untuk menjaga kesehatan sering dianggap kurang ilmiah, padahal khasiatnya telah banyak diakui oleh konsumennya, untuk itu perlu dilakukan kajian ilmiahnya. Pada saat ini juga semakin banyak ditemukan penyakit yang berhubungan degenerasi sistem metabolisme seperti penyakit kolesterol, diabetes mellitus dan stroke yang membeutuhkan pengobatan dalam jangka waktu lama. Natural product atau bahan alami dianggap lebih aman dengan efek samping relatif kecil untuk pengobatan jangka lama seperti minuman kesehatan. Sujarwo et al (2014) menyatakan bahwa etnis Bali Aga di Pulau Bali memiliki loloh yang telah 
terbukti khasiatnya dalam menjaga dan meningkatkan kesehatan termasuk penyakit diabetes mellitus.

Purwanto (2002) menyatakan bahwa etnobotani merupakan salah satu cara yang paling efektif dari segi biaya dan waktu untuk pengembangan tumbuhan obat. Para ahli etnobotani mengembangkan berbagai metode untuk mendapatkan data penelitian diantaranya melalui survei masyarakat dan survei pasar (Martin 1995). Metode survei pasar telah diterapkan Silalahi et al (2015b) untuk mendokumentasikan pengetahuan lokal pedagang tumbuhan obat di pasar Kabanjahe, Sumatera Utara dan ditemukan sekitar 245 species tumbuhan bermanfaat obat. Metode survei pasar memiliki kelebihan dibandingkan dengan dengan metode lainnya seperti: dapat mengungkapkan berbagai pengetahuan masyarakat lokal, manfaat (Silalahi dan Nisyawati 2019) dan rencana pengembangan atau bioprospeksi (van Andel dkk. 2012). Hal tersebut berhubungan dengan salah sau fungsi pasar sebagai tempat berkumpulnya berbagai kelompok masyarakat.

Pasar Pancur Batu di Kabupaten Deli Serdang, Sumatera Utara merupakan salah satu pasar tradisional tempat transaksi jual-beli tumbuhan obat dan ramuan obat. Secara geografi, pasar Pancur Batu berdekatan dengan Taman Hutan Rakyat (Tahura) Sibolangit yang kaya akan keanakaragaman hayati tumbuhan. Tahura merupakan salah satu sumber utama tumbuhan obat yang diperjual-belika di pasar Kabanjahe Berastagi (Silalahi 2014) dan Pancurbatu. Berdasarkan survei yang pedagang tumbuhan obat di pasar Pancur Batu mengembangkan berbagai ramuan tradisional untuk menjaga kesehatan salah satunya rum-rumen. Hingga saat ini penelitian rum-rumen sebagai minuman kesehatan belum banyak dilakukan. Penelitian ini bertujuan untuk mengetahui tumbuhan penyusun rum-rumen, khasiat dan bioaktivitasnya, sehingga pengembangannya dapat ditingkatkan. Bioaktivitas dari tumbuhan penyusun rum-rumen didasarkan pada kajian literature.

\section{METODE PENELITIAN}

Penelitian dilakukan dengan pendekatan ethnobotani dengan survei, wawancara dan observasi parsivatori (Martin 1995). Penelitian ini merupakan penelitian survei yang dilakukan pada pedagang tumbuhan obat di pasar Pancurbatu, Sumatera Utara. Populasi dalam penelitian ini adalah semua pedagang tumbuhan obat 
di pasar Pancurbatu, namun yang menjadi responden hanya pedagang yang menjual bahan minuman kesehatan rum-rumen.

Penelitian ini dilakukan dengan survei dan wawancara semi tersturktur. Instrumen yang digunakan berupa itemitem pertanyaan mengenai nama lokal tumbuhan, bagian yang dimanfaatkan, manfaat dan cara pembuatan minuman rum-rumen. pertanyaadalam penelitian ini berupa pengumpulan data dalam penelitian ini dilakukan dengan pendekatan etnobotani melalui survei, wawancara semi terstruktur, dan observasi parsipatori. Responden merupakan semua semua (11 orang) pedagang tumbuhan obat di pasar Pancur. Panduan yang digunakan dalam wawancara antara lain nama lokal, bagian yang dimanfaatkan, khasiat dan sumber perolehan. Voucher spesiemsn hanya dilakukan pada jenis-jenis tumbuhan yang belum diketahui nama ilmiah, kemudian dikeringkan dan diidentifikasi. Data yang diperoleh dalam penelitian ini dianalisa secara kualitatif. Analisa kualitatif meliputi pengelom-pokkan tumbuhan berdasarkan manfaat, famili, dan bagian yang dimanfaatkan. Untuk melengkapi data metabolit sekunder tumbuhan dilakukan dengan data sekunder berupa jurnal atau hasil penelitian yang telah ada sebelumnya.

\section{HASIL}

Pedagang tumbuhan obat di pasar Pancur Batu didominasi oleh perempuan dan sebagian besar merupakan sub-etnis Batak Karo berjenis kelamin perempuan dengan rentang umur antara $30-67$ tahun. Selain menjual bahan rum-rumen memperjual-belikan berbagai jenis ramuan obat maupun species tumbuhan obat. Beberapa di antara ramuan obat yang diperjual-belikan adalah tawar, minak alun, dan parem. Tawar merupakan ramuan semipadat yang dikomsumsi dengan cara menyeduh dengan air panas. Minak alun merupakan ekstrak dari berbagai jenis tumbuhan dengan menggunakan minyak kelapa (Cocos nucifera) sebagai penambah volume yang digunakan sebagai minyak gosok. Parem merupakan ramuan padat dari berbagai jenis tumbuhan padat dengan menggunakan tepung beras (Oryza sativa sebagai penambah volume).

Transaksi jual beli tumbuhan obat di pasar pancur batu termasuk rum-rumen dilakukan di dalam kios maupun di "pinggir jalan”. Jual-beli di dalam kios dilakukan pada hari Senin-Jumat, sedangkan transaksi di 'pinggir jalan" 
dilakukan pada hari Sabtu (hari pasar), sedangkan hari Minggu kios tutup karena digunakan pedagang untuk istrahat dan ibadah. Kios merupakan bagunan semi permanen dan berukuran sekitar 2-3 $\mathrm{m} \mathrm{x}$ $2 \mathrm{~m}$. Setiap kios dijaga oleh 1-2 orang pedagang dan pada umumnya merupakan anggota keluarga (anak atau menantu). Laki-laki (anggota keluarga dari pedagang) sebagian besar bertugas mengumpulkan dari pengumpul atau mencari tumbuhan obat lainnya dari ladang, kebun dan hutan. Berbagai jenis tumbuhan obat (bahkan diperkirakan hingga ratusan jenis) diperjual-belikan setiap pedagang, namun dalam artikel ini hanya difokuskan pada bahan rum-rumen sebagai minuman kesehatan.

Rum-rumen merupakan minuman kesehatan etnis Karo yang dibuat dengan cara merebus berbagai jenis tumbuhan obat. Bahan utama dari rum-rumen berasal dari 6 species tumbuhan yang berupa tumbuhan segar (Tabel 1) dan Gambar 1A. Walaupun demikian dari 6 species yang ditemukan dalam penelitian ini hanya 5 species yang berhasil diidentifikasi, sedangkan rumbane belum diidentifikasi.

Tabel 1. Nama ilmiah, lokal, bagian yang dimanfaatkan, manfaat, tumbuhan obat sebagai bahan pembuatan rum-rumen.

\begin{tabular}{|c|c|c|c|c|}
\hline Famili & Nama Ilmiah & Nama lokal & Manfaat & $\begin{array}{l}\text { Bagian yang } \\
\text { dimanfaatkan }\end{array}$ \\
\hline Amaryllidaceae & Allium chinense & $\begin{array}{l}\text { Bawang } \\
\text { batak }\end{array}$ & $\begin{array}{l}\text { Obat hipertensi, } \\
\text { kolesterol }\end{array}$ & Semua bagian \\
\hline \multirow[t]{3}{*}{ Lamiaceae } & $\begin{array}{l}\text { Ocimum } \\
\text { americanum }\end{array}$ & Kumangi & $\begin{array}{l}\text { Obat masuk angin, } \\
\text { melancarkanperedaran } \\
\text { darah, meningkatkan } \\
\text { stamina, obat sakit } \\
\text { kepala }\end{array}$ & Daun dan Batang \\
\hline & Ocimum basilicum & Tulasih & $\begin{array}{l}\text { Obat masuk angin, } \\
\text { melancarkan } \\
\text { peredaran darah, } \\
\text { mengastasi sakit } \\
\text { kepala }\end{array}$ & Daun dan Batang \\
\hline & $\begin{array}{l}\text { Plectranthus } \\
\text { amboinicus }\end{array}$ & $\begin{array}{l}\text { Terbangun } \\
\text { Rata }\end{array}$ & $\begin{array}{l}\text { Mengatasi sakit perut, } \\
\text { melancarkan } \\
\text { peredaran darah }\end{array}$ & Daun dan Batang \\
\hline \multirow[t]{2}{*}{ Poaceae } & $\begin{array}{l}\text { Cymbopogon } \\
\text { citratus }\end{array}$ & Sereh & $\begin{array}{l}\text { Obat masuk angin, } \\
\text { melancarkan } \\
\text { peredaran darah }\end{array}$ & $\begin{array}{l}\text { Pseudostem (batang } \\
\text { semu) }\end{array}$ \\
\hline & & Rumbane & $\begin{array}{l}\text { Melancarkan } \\
\text { peredaran darah }\end{array}$ & Daun dan Batang \\
\hline
\end{tabular}


Proses pembuatan minuman rum-rumen dengan cara merebus semua jenis simplisia dengan terlebih dahulu memotong-motong bahan. Setiap ikatan ramuan ditambahkan dengan $1 \mathrm{~L}$ air kemudian direbus hingga volume menjadi 0,5 L. Air hasil rebusan disaring dan diminum setiap pagi. Responden menyatakan bahwa rum-rumen diyakini berfungsi untuk mengobati sakit kepala, mengatasi gannguan saluran encernaan, melancarkan peredaran darah, mengobati hipertensi dan anti kolesterol (Tabel 1).

Bila dilihat dari komposisi tumbuhan yang digunakan sebagai bahan rum- rumen merupakan bahan yang mudah ditemukan dilingkungan sekitar dan merupakan tumbuhan yang kaya akan essensial oil. Essensial oil atau yang dikenal juga sebagai volatil oil merupakan senyawa yang mudah menguap pada suhu kamar. Secara empirik terlihat semua tumbuhan bahan rum-rumen akan menghasilkan aroma bila dilukai atau diremas. Untuk itu saya akan kaji lebih lanjut beberapa tumbuhan bahan utama rum-rumen yaitu Ocimum basilicum, Plectranthus amboinicus dan Cymbopogon citratus. Pembahasan kami dasarkan atas data sekunder yang diperoleh dari berbagai literatur ilmiah.
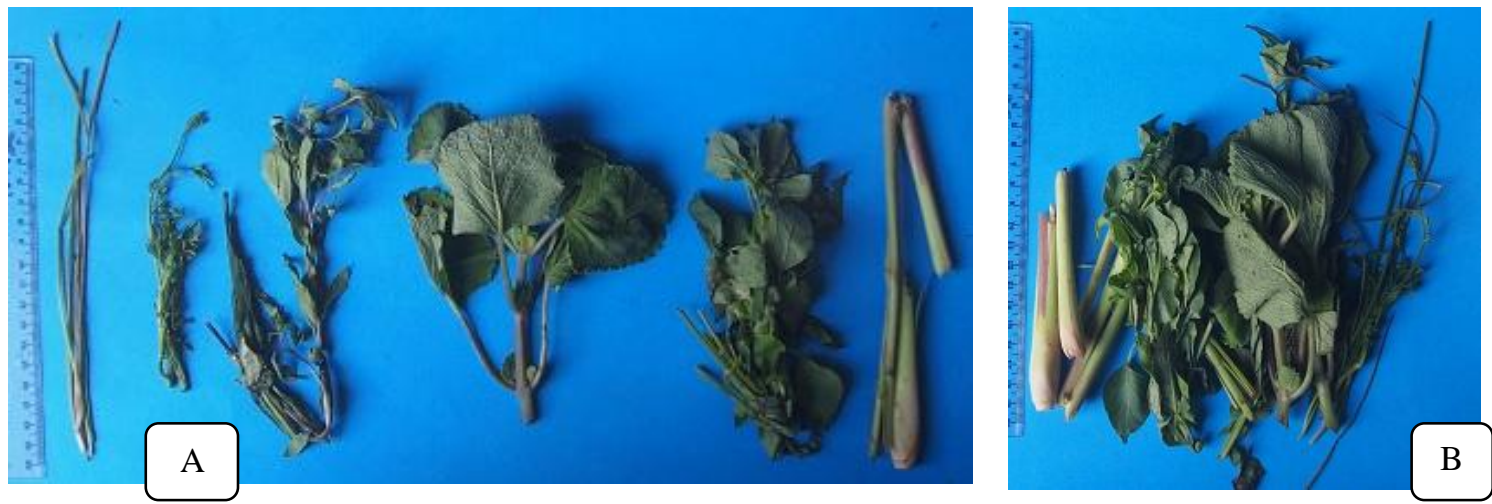

Gambar 1. A. Tumbuhan bahan pembuatan rum-rumen. Dari kiri ke kanan, bawang batak (Allium chinense), rumbane, tulasih (Ocimum basilicum), terbangun rata (Plectranthus amboinicus), kumangi (Ocimum americanum), sereh Cymbopogon citratus (Dokumentasi Pribadi). B. Bahan ramuan rum-rumen baru dibuka dari ikatan.

\section{PEMBAHASAN}

Jumlah tumbuhan yang digunakan oleh pedagang tumbuhan obat di pasar Pancurbatu relatif sama antara satu pedagang dengan pedagang lainnya.
Terdapat beberapa variasi dalam yang dimiliki pedagang yaitu volume tumbuhan obat yang diperjual-belikan. Silalahi et al (2015) menyatakan bahwa volume tumbuhan obat yang diperjual- 
belikan oleh pedagang dipengaruhi oleh luas kios, modal dan lama berdagang. Pada umumnya pedagang dengan modal dan lama berdagang berbanding lurus dengan volume tumbuhan obat yang diperjual-belikan termasuk bahan rumrumen.

Pengembangan minuman kesehatan yang diangkat dari kearifan lokal memiliki kelebihan karena toksisitasnya telah teruji sejak ratusan tahun. Hal yang sama juga berlaku pada minuman rum-rumen yang digunakan oleh sub-etnis Batak Karo di Pancur Batu. Semua bahan yang digunakan mudah ditemukan di lingkungan sekitar dan telah banyak dibudidayakan. Untuk memperkuat hal tersebut maka kami lakukan kajian mendalam terhadap beberapa bahan utama rum-rumen meliputi serai (Cymbopogon citratus), tulasih (Ocimum basilicum) dan terbangun rata (Ocimum basilicum).

\section{Sereh (Cymbopogon citratus (DC) Stapf)}

Cymbopogon citratus atau yang dikenal juga dengan sereh merupakan salah satu jenis tanaman yang telah lama digunakan dalam berbagai masakan di Indonesia maupun industri minuman. Pemberian sereh pada minuman akan memberi aroma khas dan memberi efek yang menyegarkan. Oyen dan Dung (1999) menyatakan aroma yang dihasilkan tumbuhan berhubungan dengan senyawa yang mudah menguap berupa senyawa volatil oil dan essential oil (Oyen dan Dung, 1999). Abena et al (2007) menyatakan bahwa essential oil utama yang ditemukan pada C. citratus berasal dari golongan monoterpen terutama sitronelal dan geraniol (Abena et al 2007).

Khasiat C. citratus dalam bidang kesehatan telah banyak diteliti dan sangat potensial dikembangkan menjadi obat tradisional, herbal terstandar maupun fitofarmaka. Martinazzo et al., (2009) meyatakan bahwa di Brasil telah dikembangkan "teh" dengan menggunakan C. citratus sebagai komponen utamanya. Bioakticitas $C$. citratus telah terbukti sebagaiantiinflamasi, antimikroba (Manvitha dan Bidya, 2014), dan antioksidan (Garcia, et al. 2015).

Bila ditelusur lebih lanjut penelitian $C$. citratus biaoktivitas sebagai antimikroba banyak dilaporkan yaitu menghambat pertumbuhan Staphylococcus aureus, Bacillus aureus, Bacillus subtilis, Escherichia coli, Klebsilela pneumoniae, Pseudomonas aeruginosa 
(Naik et al 2010). Mikroba tersebut merupakan mikroba patogen yang mengakibatkan infeksi saluran pencernaan dan saluran pernapasan. Pengembangan natural produk sebagai anti mikroba perlu terus dikembangkan karena berbagai fakta menunjukakan resisten mikroba terhadap obat yang ada.

Selain sebagai antimikroba Bioaktivitas $C$. citratus sebagai antiinflamasi telah banyak dilaporkan oleh peneliti di antaranya Hosseinzadeh dan Younesi (2002) dan Garcia et al. (2015). Bioaktivitas C. citratus sebagai anti inflamasi dihubungkan dengan senyawa polifenol terutama flavonoid dan tannin (Hosseinzadeh dan Younesi, 2002). Garcia, et al., (2015) juga melaporkan C. citratus berfungsi untuk mengurangi atau menghilangkan rasa sakit. Lebih lanjut dinyatakannya bahwa ekstrak daun $C$. citratus mengurangi rasa nyeri pada saraf tepi tikus sebesar 57\% dengan dosis $(136,48 \mathrm{mg} / \mathrm{kg}$ ) (Garcia, et al., 2015).

\section{Tulasih (Ocimum basilicum L.)}

Ocimum basilicum merupakan salah satu species dari famili Lamiaceae yang digunakan sebagai penghasil essensial oil. Silalahi dan Nisayawati (2019) O. basilicum merupakan salah satu komponen utama sauna tradisional etnis Batak di Sumatera
Utara. Aroma yang dihasilkan dari bahan sauna termasuk $\mathrm{O}$. basilicum memberi efek yang menyenangkan atau memeberi efek relaksasi. Pemanfaatan O. basilicum juga dalam minuman rum-rumen diyakini memberi efek yang menyenangkan. Selain masayaraat lokal Indonesia berbagai pengobatan tradisional memanfaatkan $O$. basilicum sebagai obat karminatif, sakit perut dan antispasmodial, mual, kembung, dan disentri (Ozcan dan Chalchat, 2002; Sajjadi, 2006). Zarlaha et al, (2014) menyatakan bahwa O. basilicum mengandung hingga $1,5 \%$ minyak esensial, yang komposisinya paling banyak adalah linalool dan eugenol. SaidAl Ahl et al. (2015) menyatakan bahwa konsentrasi eugenol dan linalool yang ditemukan pada $O$. basilicum saling berlawanan yaitu ketika konsentrasi eugenol meningkat maka konsentrasi linalool menurun dan sebaliknya (Said-Al Ahl et al., 2015).

Selain linalool dan eugenol ternyata masih banyak jenis essensial oil lainnya yang terkandung dalam O. basilicum. Beatovic et al. (2015) menyatakan bahwa sebanyak 75 senyawa essensial oil telah berhasil diidentifikasi pada O. basilicum (Beatovic et al., 2015). Walaupun demikian kandungan essensial oil $O$. basilicum sangat bervariasi 
sangat dipengaruhi oleh umur, cara ekstraksi dan asalnya.

Berbagai peneliti telah melaporkan bioaktivitas $O$. basilicum yaitu antioksidan (Beatovic et al., 2015), anti bakteri (Moghaddam et al., 2011; Unnithan et al., 2013) dan anti kanker (Zarlaha et al., 2014). Hal yang hampir mirip dengan C. citratus bahwa pemanfaatan $\mathrm{O}$. basilicum sebagai antimikroba lebih menonjol terutama sebagai anti bakteri (Moghaddam et al., 2011; Unnithan et al. 2013). Ekstrak O. basilicum dapat memenghambat pertumbuhan bakteri gram-negative (Escherichia coli, Pseudomonas aeruginosa) dan bakteri gram positif (Bacillus cereus, Staphylococcus aureus) (Moghaddam et al., 2011). Unnithan et al. (2013) menyatakan bahwa biaktivitas O. basilicum sebagai anti bakteri terhadap Gram positif lebih tinggi dibandingkan bakteri gram negatif.

Selain sebagai anti bakteri, Zarlaha et al. (2014) melaporkan biaoktivitas O basilicum sebagai anti kanker pada sel kanker serviks adenokarsinoma sel HeLa, sel melanoma manusia FemX, sel myelogenous leukemia K562 kronis, dan sel ovarium manusia SKOV3 secara in vitro. Bioktivitas O. basilicum sebagai anti kanker juga dihubungkan dengan kandunggan essensial oilnya. Dengan demikian minuman tradisional termasuk rum-rumen juga sangat potensial dikembangkan sebagai minuman untuk mencegah penyakit kanker. Hal yang sama juga dinyatakan Sujarwo et (2014) bahwa loloh yang dikembangkan masyarakat lokal Bali Aga diyanini juga sebagai anti kanker.

\section{Terbangun rata (Plectranthus amboinicus (Lour.) Spreng}

Sebayak 3 species tumbuhan yang digunakan sebagai bahan rum-rumen berasal dari famili Lamiaceae termasuk Plectranthus amboinicus. Pemanfaatan $P$. ambonicus sebagai bahan minuman kesehatan belum pernah dilaporkan sehingga penelitian ini menjadi sala satu acuan dalam pengembanngan sebagai minuman kesehatan. Silalahi (2014) P. ambonicus lebih dikenal sebagai makanan (sayur) yang diyakini dapat meningkatkan prosuksi air susu ibu pasca melahirkan. Walaupun demikaian pemanfaatannya sebagai obat tradisional banyak dimanfaatkan oleh masyarakat lokal India sebagai obat demam malaria, ginjal, batuk, asma kronis, dan bronkitis (Hullatti dan Bhattacharjee 2011).

Bila ditelusuri penelitian pemanfaatan P. ambonicus sebagai anti mikroba juga 
telah dilaporkan (Wadikar dan Patki 2016; El-hawary et al. 2013; Goncalves et al. 2012; Bhatt et al. 2013) dan anti kanker (Thirugnanasampandan et al. 2015; Bhatt et al. 2013; Seca et al. (2018)). Senyawa bioaktif dari daun $P$. amboinicus menghambat pertumbuhan berbagai jenis bakteri sepeerti Klebsiella pneumoniae (Goncalves et al. 2012), Staphylococcus aureus (Manjamalai et al. 2012; Bhatt et al. 2013), Bacillus cereus, Escherichia coli, dan Yersinia enterocolitica (Bhatt et al. 2013), Bacillus subtilis (Bhatt dan Negi 2012; Astuti et al. 2012), Klebsiella planticola (Vanaja dan Annadurai 2013), Pseudomonas aeruginosa (Manjamalai et al. 2012; Astuti et al. 2012), S. aureus and S. thypi, (Astuti et al. 2012). Bakteri tersebut merupakan bakteri yang menginfeksi saluran pencernaan dan saluran pernapasan. Oleh karena itu komsumsi minuman rumrumen diyakini akan menyehatkan salauran pencernaan dan saluran pernapasan seperti yang dinyatakan oleh responden.

Selain sebagai anti bakteri, bioaktivitas P. ambonicus sebagai anti kanker juga telah banyak dilaporkan. Hasibuan (2014) menyakan bahwa ekstrak n-hexane, ethylacetate metanol, dan ethanol dari $P$. amboinicus bersifat sitotoksik pada HeLa dengan nilai IC50 sebesar $76.322 \mu \mathrm{g} / \mathrm{mL}$,
$143.291 \mu \mathrm{g} / \mathrm{mL}$, dan $88.997 \mu \mathrm{g} / \mathrm{mL}$ secara berurutan. Thirugnanasampandan et al. (2015) melaporkan esensial oil P. ambonicus bersifat sitotoksik terhadap sel kanker payudara (MCF-7) dan sel kanker kolorektal (HT-29). Bioaktivitas P. ambonicus sebagai anti kanker berhubungan dengan senyawa $\gamma$ terpinene, $\mathrm{p}$-cymene, $\beta$ - caryophyllene dan $\alpha$-humulene (Thirugnanasam-pandan et al. 2015).

\section{KESIMPULAN}

Sebanyak 6 species tumbuhan obat yang berasal dari 3 famili digunakan sebagai bahan rum-rumen dan merupakan tumbuhan yang kaya akan kandungan essensial oil. Manfaat rumrumen adalah melancarkan peredaran darah, mengatasi sakit kepala, mengatasi gangguan saluran pencernaan, mengobati kolesterol dan juga anti hipertensi. Rum-rumen sangat potensial dikembangkan sebagai minuman antimikroba dan anti kanker.

\section{UCAPAN TERIMA KASIH}

Penulis mengucapkan terima kasih kepada semua pedagang tumbuhan obat yang telah bersedia memberikan informasi dalam penelitian ini dan Ibu Nisyawati yang membantu pendanaan penelitian ini. 


\section{REFERENSI}

Abena, A., Gbenou, J.D., Yayi, E., Moudachirou, M., Ongoka, R.P., Ouamba, J.M., \& Silou, T. (2007). Comparative chemical and analgesic properties of essential oils of Cymbopogon nardus (L) Rendle of Benin and Congo. Afr. J. Trad. CAM 4(2), 267- 272.

Asiimwe, S., Borg-Karlsson, A.K., Azeem, M., Mugisha, K.M., Namutebi A., and Gakunga, N.J. (2014). Chemical composition and toxicological evaluation of the aqueous leaf extracts of Plectranthus amboinicus Lour. Spreng. International Journal of Pharmacentical Science Invention 3(2): 19-27.

Astuti, P., Sudarsono, S., Nisak, K., and Nugroho, G.W. (2014). Endophytic fungi isolated from Coleus amboinicus Lour exhibited antimicrobial activity. Adv Pharm Bull, 4(Suppl 2): 599-605.

Bhatt, P., Joseph, G.S., Negi, P.S., and Varadaraj, M.C. (2013). Chemical composition and nutraceutical potential of indian borage (Plectranthus amboinicus) stem extract. Hindawi Publishing Corporation Journal of Chemistry, Article ID 320329, 7 pages

Beatovic, D., Krstic-Miloševic, D., Trifunovic, S., Šiljegovic, J., Glamoclija, J., Ristic, M., and Jelacic, S.(2015). Chemical composition, antioxidant and antimicrobial activities of the essential oils of twelve Ocimum basilicum L. cultivars grown in Serbia Rec. Nat. Prod. 9(1): 62-75.

El-hawary, S.S., El-sofany, R.H., AbdelMonem, A.R., Ashour, R.S., and Sleem, A.A. (2013). Seasonal variation in the composition of Plectranthus amboinicus (Lour.) Spreng essential oil and its biological activities. American Journal of Essential Oils and Natural Products 1(2): 11-18.

Garcia, R., Ferreira, J.P., Costa, G., Santos, T., Branco, F., Caramona, M., de Carvalho, R., Dinis, A.M., Batista, M.T., Castel-Branco, M., \& Figueiredo, I.V. (2015). Evaluation of anti-inflammatory and analgesic activities of Cymbopogon citratus in vivo-polyphenols contribution. Research Journal of Medicinal Plant 9(1):1-13.

Goncalvesa, T.B., Braga, M.A., de Oliveiraa, FF.M., Santiago, G.G.M.P. Carvalho, CB.M., Cabrala, P.B., Santiago, T.D.M., Sousa, J.S., Barros, E.B., do Nascimentog, R.F., Nagao-Dias, A.T. (2012). Effect of sub inihibitory and inhibitory concentrations of Plectranthus amboinicus (Lour.) Spreng essential oil on Klebsiella pneumoniae. Phytomedicine 19: 962- 968.

Hullatti, K.K., and Bhattacharjee, P. 2011. Pharmacognostical evaluation of different partsof Coleus amboinicus lour., Lamiaceae. Pharmacognosy Journal 3(24): 39-44.

Manjamalai, A., Alexander, T. and Grace, V.M.B. (2012). Bioactive evaluation of the essential oil of plectranthus amboinicus by GC-MS analysis and its role as a drug for microbial infections and inflammation. Int J Pharm Pharm Sci, 4(3): 205-211

Martinazzo, A.P., Melo, E.C., Barbosa, L.C.D.A., Soares, N.D.F.F., Rocha, R.P., Randuz, L.L., \& Berbert, P.A. (2009) Quality parameters of Cymbopogon Citratus leaves during ambient storage. Applied Engineering in Agriculture 25(4): 543-547.

Martin, G.J. (1995). Ethnobotany a People and Plants Conservation Manual. Chapman and Hall. London, UK: $\mathrm{xi}+268 \mathrm{hlm}$. 
Moghaddam, A.M.D., Shayegh, J., Mikaili, P., and Shara, J.D. (2011). Antimicrobial activity of essential oil extract of Ocimum basilicum L. leaves on a variety of pathogenic bacteria. Journal of Medicinal Plants Research 5(15): 3453-3456.

Naik, M.I., Fomda, B.A., Jaykumar, E., and Bhat, J.A. (2010). Antibacteri-al activity of lemon grass (Cymbopogon citratus) oil agains some selected pathogenic bacteria. Asian Pasific Journal of Tropical Medicine, 535-538.

Oyen, L.P.A., and N.X. Dung (Editors). (1999). Plants Resources of Souths-East Asia No. 19. Backhyuys Publisher, Leiden, the Netherland 277 pp.

Özcan, M., and Chalchat, J.C. (2002). Essential oil composition of Ocimum basilicum L. and Ocimum minimum L. in Turkey. Czech J. Food Sci. 20: 223-228.

Purwanto, Y. (2002). Studi Etnomedisinal dan Fitofarmakope Tradisional Indonesia. Prosiding Seminar Nasional II Tumbuban Obat dan Aromatik. LIPI, Bogor: 96-109.

Said-Al Ahl, H.A.H. and Mahmoud, A.A. (2010). Effect of zinc and / or iron foliar application on growth and essential oil of sweet basil (Ocimum basilicum L.) under salt stress. Ozean Journal of Applied Sciences 3(1): 97-111.

Said-Al Ahl, H.A.H., Meawad, A.A., Abou-Zeid, E.N.,andAli, M.S. (2015). Evaluation of volatile oil and its chemical constituents of some basil varieties in Egypt.International Journal of Plant Science and Ecology 1(3): 103-106.

Sajjadi, S.E. (2006). Analysis of the essential oils of two cultivated basil (Ocimum basilicum L.) from Iran. Daru 14(3): 128-130.

Seca, A.M.L., and Pinto, D.C.G.A. (2018). Plant secondary metabolites as anticancer agents: successes in clinical trials and therapeutic application. Int. J. Mol. Sci. 19(263): 1-22.

Silalahi, M., Nisyawati, Walujo, E.B., Supriatna, J., and Mangunwardoyo, W. (2015). The local knowledge of medicinal plants trader and diversity of medicinal plants in the Kabanjahe traditional market, North Sumatra, Indonesia. Journal of Ethnopharmacology 175, 432-443.

Silalahi, M.and Nisyawati.(2019). An ethnobotanical study of traditional steam-bathing by the Batak people of North Sumatra, Indonesia. Pacific Conservation Biology 25(3): 266-282.

Silalahi, M.(2014). The ethnomedicine of the medicinal plants in sub-ethnic Batak, North Sumatra and the conservation perspective, [Dissertation] Indonesia Universitas Indonesia.

Sujarwo, W., Keim, A.P., Savo, V., Guarrera,P.M. and Caneva, G. (2014). Ethnobotanical study of Loloh: Traditional herbal drinks from Bali (Indonesia). Journal of Ethnopharmacology 169: 34-48.

Thirugnanasampandan, R., Ramya, G., Gogulramnatha, M., Jayakumar, R., and Kanthimathi, M.S. (2015). Evaluation of cytotoxic, DNA protecting and LPS induced MMP9 down regulation activities of Plectranthus amboinicus (Lour) Spreng essential oil. Pharmacognosy Journal 7(1): 32-36.

Unnithan, C.R., Dagnaw, W., Undrala, S. and Ravi, S. (2013). Chemical Composition and Antibacterial activity of Essential oil of Ocimum basilicum of Northern Ethiopia International Research Journal of Biological Sciences 2(9): 1-4.

van Andel, T., Myren, B.,and van Onselen, S. (2012). Ghana Herbal Market. Journal of Ethnopharma-cology 30: 1-11.

Wadikar, D.D., and Patki, P.E. (2016). Coleus aromaticus: a therapeutic herb 
with multiple potentials. J Food Sci Technol. 53(7): 2895-2901.

Wakhidah, A.Z. (2015). Etnobotani upacara penyambutan kedewasa-an gadis (Ake sou) pada beberapa etnis di Halmahera Barat, Skripsi. Departemen Biologi, Fakultas Matematika dan Ilmu Pengetahuan Alam, Universitas Indonesia, Depok, xi +80 hal.
Zarlaha, A., Kourkoumelis, N., Stanojkovic, T.P. Kovala-Demertzi D. (2014). Cytotoxic activity of essential oil and extracts of Ocimum basilicum against human carcinoma cells. Molecular docking study of isoeugenol as a potent cox and loxinhibitor. Digest Journal of Nanomaterials and Biostructures 9(3): 907-917. 